\title{
Effects of Macrophyte Species and Density on Algae Inhibition and Water Purification in Submerged Macrophyte Ponds
}

\author{
Yi Ding1,2, Yuan Sun¹, Haiyan Tang ${ }^{1}$, Xinshan Song* \\ ${ }^{1}$ College of Ocean Science and Engineering, Center for Marine Environmental and Ecological Modelling, \\ Shanghai Maritime University, Shanghai, China \\ ${ }^{2}$ College of Environmental Science and Engineering, State Environmental Protection Engineering Center for Pollution \\ Treatment and Control in Textile Industry, Donghua University, Shanghai, China
}

Received: 16 August 2019

Accepted: 27 October 2019

\begin{abstract}
Submerged macrophytes are capable of inhibiting algae growth and removing nutrients from water with cost-effective and ecofriendly properties. The purification efficiency of three submerged macrophytes (Ceratophyllum demersum, Myriophyllum spicatum, and Vallisneria natans) was systematically compared in submerged macrophyte ponds (SMPs). Twelve SMP reactors divided into three groups were constructed to treat synthetic eutrophic wastewater throughout the summer and autumn season. The results demonstrated that higher macrophyte density could promote water purification performance. Summer tests exhibited better removal performance than autumn tests. Based on comprehensive consideration, constructing high-quality-concentration Myriophyllum spicatum pond in summer season was the optimal design and operation of SMPs, in which $43.8 \pm 2.0 \% \mathrm{TN}, 97.8 \pm 1.0 \%$ TP, $99.0 \pm 1.0 \%$ DCOD, and $68.7 \pm 3.0 \%$ algae biomass could be reduced.
\end{abstract}

Keywords: submerged macrophyte ponds, macrophyte species and density, algae inhibition, water purification

\section{Introduction}

Intense algae blooms caused by eutrophication have represented a serious threat to freshwater ecosystems and drinking water safety [1]. Algae inhibition and reducing the discharge of nitrogen $(\mathrm{N})$ and phosphorus (P) were indentified as the two main nutrients for eutrophication that could enhance water clarity and

*e-mail: newmountain@dhu.edu.cn improve water quality [2]. Conventional technologies for the restoration of eutrophic water involve high investment and operational costs, including mechanical removal of algae, the addition of algaecide, the application of chemical reagents and artificial aeration [3-4]. In recent years, phytoremediation technology has been increasingly studied due to its cost-effective and ecofriendly properties compared to conventional remediation techniques [5]. Phytoremediation promotes water purification by utilizing the photosynthetic aeration of aquatic macrophytes driving biochemical reaction in the rooting zone, including decomposition of organics 
via aerobic bacteria and microbial nitrification process under aerobic conditions. Submerged macrophyte is an important composition of freshwater ecosystems, which is characterized by fast growing and stress-tolerant properties [6]. They can provide abundant oxygen and root surface area for microbial reaction and growth. In addition, submerged macrophytes are conducive to reducing sediment resuspension, absorbing nutrients from water, and excreting allelopathic substances into water for algae inhibition [7-8]. Thus water clarity is often improved in areas with dense macrophytes. In summary, constructing submerged macrophyte ponds (SMPs) for algae inhibition and the alleviation of nutrient loads is an efficient phytoremediation approach toward the ecological restoration of eutrophic water.

SMP performance depends on macrophyte species and biomass, while macrophyte growth is mainly affected by seasonal variation [9]. However, the effects of macrophyte species and density on algae inhibition and water purification in SMPs have not been well studied, which has impeded optimization on design and operation of SMPs. Three kinds of common submerged macrophytes (Ceratophyllum demersum, Myriophyllum spicatum and Vallisneria natans) were selected as the experimental subjects in SMPs. Simultaneously, the effect of macrophyte density under seasonal variation (summer and autumn) on algae inhibition and pollutant removal was evaluated in SMPs.

\section{Material and Methods}

This experiment was performed in 12 lab-scale SMP reactors in Shanghai, China $\left(38^{\circ} 39^{\prime} 27^{\prime \prime} \mathrm{N}, 104^{\circ} 04^{\prime} 58^{\prime \prime} \mathrm{E}\right)$. The dimension (length $\times$ width $\times$ height) of each SMP reactor was $0.96 \mathrm{~m} \times 0.60 \mathrm{~m} \times 0.60 \mathrm{~m}$ and the total working volume was $300 \mathrm{~L}$. Inlet and outlet tubes were respectively arranged on the two sides of each SMP. 10 -cm-thick layers of fine gravel $(\Phi=1.5-2.0 \mathrm{~cm})$ and 5 -cm-thick layers of washed sand $(\Phi<0.2 \mathrm{~cm})$ were spread on the bottom of each SMP reactor to facilitate the growth of submerged macrophytes. Perennial submerged macrophytes of Ceratophyllum demersum, Myriophyllum spicatum and Vallisneria natans - widely present in freshwater habitats and eutrophic lakes were obtained from Chen Shan Botanical Garden, Shanghai, China $\left(31^{\circ} 04^{\prime} 37.28^{\prime \prime} \mathrm{N}, 121^{\circ} 10^{\prime} 42.76^{\prime \prime} \mathrm{E}\right)$. The macrophytes were cleaned and pre-cultured for two weeks before the experiments were started. All three macrophytes with uniform growth $(35 \pm 5 \mathrm{~cm})$ and similar biomass $(30 \pm 5 \mathrm{~g})$ were selected for subsequent experiments. Synthetic eutrophic wastewater was added into experimental units from inlet tanks by peristaltic pumps and the total inflow was $250 \pm 5 \mathrm{~L}$ within $1 \mathrm{~h}$. The SMPs were operated intermittently and hydraulic retention time (HRT) was $3 \mathrm{~d}$. Microcystis aeruginosa used in this study is a common cyanobacterium in freshwater ecosystems. It was obtained from the freshwater algae culture collection at the Institute of Hydrobiology, Chinese Academy of Sciences (FACHB, Wuhan City, China). Tables 1 and 2 show the basic composition of experimental wastewater.

The experiments should be divided into two phases: summer tests (June to August) and autumn tests (September to November). Temperature ranges in summer tests and autumn tests were $25-35^{\circ} \mathrm{C}$ and $10-20^{\circ} \mathrm{C}$, respectively. Twelve SMP reactors were divided into three groups: the high-quality concentration submerged macrophyte group in summer months (SMP-A), the low-quality concentration submerged macrophyte group in summer months (SMP-B), and

Table 1. Variations of M. aeruginosa with HRT in experimental reactors.

\begin{tabular}{|c|c|c|c|c|c|c|}
\hline \multirow{2}{*}{$\begin{array}{l}\text { Influent algae concentration } \\
\left(\text { cells } \mathrm{mL}^{-1}\right)\end{array}$} & \multirow{2}{*}{\multicolumn{2}{|c|}{ Systems }} & \multicolumn{3}{|c|}{ Effluent algae concentration (cells mL $\mathrm{mL}^{-1}$ ) } & \multirow{3}{*}{$\begin{array}{c}\text { Removal (\%) } \\
--\end{array}$} \\
\hline & & & 1d-HRT & 2d-HRT & 3d-HRT & \\
\hline \multirow{4}{*}{$11500 \pm 500$} & \multirow{4}{*}{ SMP-A } & C. demersum & $12720 \pm 200$ & $17305 \pm 200$ & $18080 \pm 200$ & \\
\hline & & M.spicatum & $12320 \pm 200$ & $6442 \pm 200$ & $3434 \pm 200$ & $68.7 \pm 3.0$ \\
\hline & & V.natans & $8527 \pm 200$ & $3508 \pm 200$ & $2774 \pm 200$ & $38.5 \pm 3.0$ \\
\hline & & Control & $16159 \pm 200$ & $17643 \pm 200$ & $22134 \pm 200$ & -- \\
\hline \multirow{4}{*}{$12000 \pm 500$} & \multirow{4}{*}{ SMP-B } & C. demersum & $16720 \pm 200$ & $19354 \pm 200$ & $21898 \pm 200$ & -- \\
\hline & & M.spicatum & $14935 \pm 200$ & $12359 \pm 200$ & $12161 \pm 200$ & -- \\
\hline & & V.natans & $12527 \pm 200$ & $8969 \pm 200$ & $8145 \pm 200$ & $29.5 \pm 3.0$ \\
\hline & & Control & $18102 \pm 200$ & $20343 \pm 200$ & $22933 \pm 200$ & -- \\
\hline \multirow{4}{*}{$11800 \pm 500$} & \multirow{4}{*}{ SMP-C } & C. demersum & $12593 \pm 200$ & $13440 \pm 200$ & $13089 \pm 200$ & -- \\
\hline & & M.spicatum & $11845 \pm 200$ & $11950 \pm 200$ & $11835 \pm 200$ & $2.9 \pm 3.0$ \\
\hline & & V.natans & $10987 \pm 200$ & $10633 \pm 200$ & $9390 \pm 200$ & $21.1 \pm 3.0$ \\
\hline & & Control & $13796 \pm 200$ & $15329 \pm 200$ & $17012 \pm 200$ & -- \\
\hline
\end{tabular}


the high-quality concentration submerged macrophyte group in autumn months (SMP-C). Each group contained four SMP reactors, including Ceratophyllum demersum pond, Myriophyllum spicatum pond, Vallisneria natans pond, and control pond. The control unit did not contain any submerged macrophytes. Quality concentration of submerged macrophytes (QC-SM) was calculated as per the following equation:

QC-SM $\left(\mathrm{g} \mathrm{L}^{-1}\right)=\frac{\text { Number of submerged macrophytes } \times \text { Weight of submerged macrophytes }}{\text { Total }}$

QC-SM $\left(\mathrm{g} \mathrm{L}^{-1}\right)=\mathrm{QC}-\mathrm{SM}$ in SMP-A and SMP-C was maintained at $7.5 \pm 0.5 \mathrm{~g} \mathrm{~L}^{-1}$ while QC-SM in SMP-B was maintained at $3.2 \pm 0.5 \mathrm{~g} \mathrm{~L}^{-1}$.

Experiments were performed in triplicate. After each round of the experiment, equal submerged macrophytes would be replanted into each SMP for keeping the consistence of experimental conditions. Temperature and $\mathrm{pH}$ were determined immediately using a $\mathrm{pH}$ meter with temperature sensor (HI 9125, HANNA, Italy), and dissolved oxygen (DO) was determined using a DO meter (HI 9143, HANNA, Italy). Chlorophyll a (Chl-a) concentrations were determined using a portable water quality multi-probe (Manta 2, EURERA, USA). Total nitrogen (TN), ammonia nitrogen $\left(\mathrm{NH}_{4}-\mathrm{N}\right)$, total phosphorus (TP), and dissolved chemical oxygen demand (DCOD) were measured using a multiparameter colorimeter (DR900, HACH, USA). Samples were filtered through Whatman GF/C glass filters (0.22 $\mu \mathrm{m}$ pore size) for analysis.

All data are presented as mean \pm standard deviation (S.D.) of triplicate samples. Statistical analyses were performed with Origin 8.0 (OriginLab, MA, USA) statistical software, and significant differences between data sets were determined by ANOVA tests. Results were considered significant at $p<0.05$.

\section{Results and Discussion}

The variations of algae concentration with HRT in experimental reactors are shown in Table 1. Fig. 1 presents the profiles of Chl-a in experimental units. As demonstrated by Table 1 and Fig. 1, Chl-a content of control pond in three groups increased sharply with HRT. During the experimental stage, the effluent algae concentration in three kinds of SMPs was lower than that in control ponds. Algae inhibition in SMPs was possibly caused by the allelopathic effect of submerged macrophytes [10-11]. The algae biomass was higher in the Ceratophyllum demersum pond compared with that in Myriophyllum spicatum and Vallisneria natans ponds. The results implied that Myriophyllum spicatum and Vallisneria natans could be more effective in algae inhibition than Ceratophyllum demersum. Effluent algae content in Myriophyllum spicatum and Vallisneria natans ponds of SMP-A were significantly lower than that of SMP-B $(p<0.05)$, indicating that higher macrophyte density in SMP-A had a positive effect on

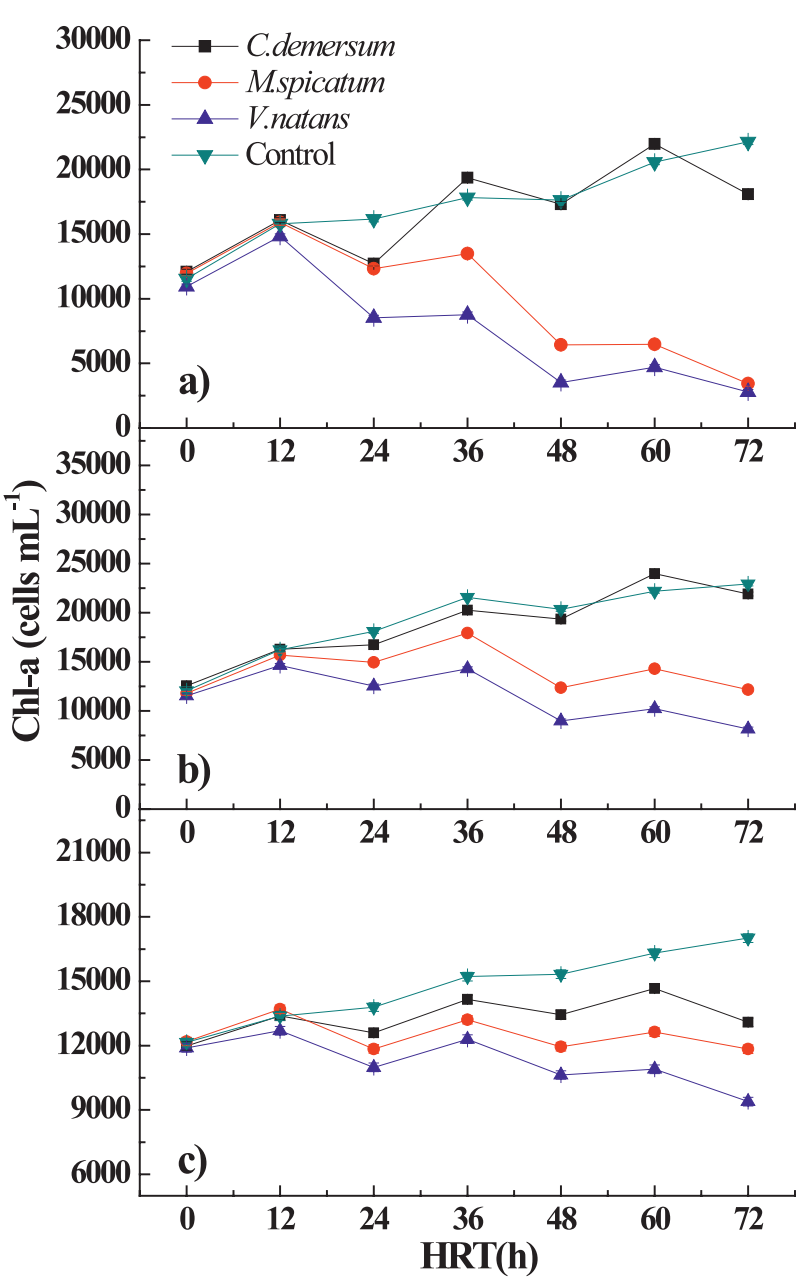

Fig. 1. Profiles of Chl-a in SMP-A a), SMP-B b) and SMP-C c).

algae inhibition through releasing more allelopathic substances into waters compared with SMP-B. After 72-h HRT, algae removal in Myriophyllum spicatum and Vallisneria natans ponds of SMP-A was higher than that in Vallisneria natans pond of SMP-B. Compared with the summer tests, the algae inhibition in SMP-C during the autumn tests was limited. Lowtemperature conditions restricted the growth of submerged macrophytes, which further affected the excretion of allelopathic substances via submerged macrophytes [12]. The maximum removal of algae in Myriophyllum spicatum and Vallisneria natans ponds of SMP-C reached $2.9 \pm 2.0 \%$ and $21.1 \pm 3.0 \%$. Submerged macrophyte species and density exerted a great effect on algae removal, while the favorable temperature was an important environmental factor for promoting growth and allelopathy of submerged macrophytes [13].

Pollutant removal performance of experimental systems is shown in Table 2. Fig. 2 presents the profiles of DCOD, TN and TP in experimental units. Nitrogen absorption via submerged macrophytes is limited, while aerobic nitrification can have a significant influence on the conversion and removal of $\mathrm{NH}_{4}-\mathrm{N}$ [14]. The results showed that Ceratophyllum demersum and Myriophyllum spicatum ponds exhibited higher 
Table 2. Pollutant removal performance of experimental systems (note: a indicates HRT of $72 \mathrm{~h}$ and b indicates HRT of $48 \mathrm{~h}$ ).

\begin{tabular}{|c|c|c|c|c|c|}
\hline Parameter & Influent (mg L-1) & \multicolumn{2}{|c|}{ Systems } & Effluent (mg L-1) & Removal (\%) \\
\hline \multirow{9}{*}{$\mathrm{NH}_{4}-\mathrm{N}$} & \multirow{9}{*}{$16.5 \pm 1.5$} & \multirow{3}{*}{ SMP-A } & C. demersum & $6.8 \pm 0.5^{\mathrm{a}}$ & $56.8 \pm 2.0^{\mathrm{a}}$ \\
\hline & & & M.spicatum & $7.2 \pm 0.5^{\mathrm{a}}$ & $55.1 \pm 2.0^{\mathrm{a}}$ \\
\hline & & & V.natans & $8.3 \pm 0.5^{\mathrm{a}}$ & $48.4 \pm 2.0^{\mathrm{a}}$ \\
\hline & & \multirow{3}{*}{ SMP-B } & C. demersum & $7.6 \pm 0.5^{\mathrm{a}}$ & $55.2 \pm 2.0^{\mathrm{a}}$ \\
\hline & & & M.spicatum & $7.9 \pm 0.5^{\mathrm{a}}$ & $52.9 \pm 2.0^{\mathrm{a}}$ \\
\hline & & & V.natans & $9.5 \pm 0.5^{\mathrm{a}}$ & $46.2 \pm 2.0^{\mathrm{a}}$ \\
\hline & & \multirow{3}{*}{ SMP-C } & C. demersum & $9.0 \pm 0.5^{\mathrm{a}}$ & $49.3 \pm 2.0^{\mathrm{a}}$ \\
\hline & & & M.spicatum & $9.3 \pm 0.5^{\mathrm{a}}$ & $45.7 \pm 2.0^{\mathrm{a}}$ \\
\hline & & & V.natans & $9.8 \pm 0.5^{\mathrm{a}}$ & $42.4 \pm 2.0^{\mathrm{a}}$ \\
\hline \multirow{9}{*}{$\mathrm{TN}$} & \multirow{9}{*}{$17.5 \pm 1.5$} & \multirow{3}{*}{ SMP-A } & C. demersum & $9.0 \pm 0.5^{\mathrm{a}}$ & $44.8 \pm 2.0^{\mathrm{a}}$ \\
\hline & & & M.spicatum & $9.5 \pm 0.5^{\mathrm{a}}$ & $43.8 \pm 2.0^{\mathrm{a}}$ \\
\hline & & & V.natans & $10.7 \pm 0.5^{\mathrm{a}}$ & $37.4 \pm 2.0^{\mathrm{a}}$ \\
\hline & & \multirow{3}{*}{ SMP-B } & C. demersum & $10.0 \pm 0.5^{\mathrm{a}}$ & $43.6 \pm 2.0^{\mathrm{a}}$ \\
\hline & & & M.spicatum & $10.5 \pm 0.5^{\mathrm{a}}$ & $41.5 \pm 2.0^{\mathrm{a}}$ \\
\hline & & & V.natans & $12.0 \pm 0.5^{\mathrm{a}}$ & $34.4 \pm 2.0^{\mathrm{a}}$ \\
\hline & & \multirow{3}{*}{ SMP-C } & C. demersum & $11.1 \pm 0.5^{\mathrm{a}}$ & $39.6 \pm 2.0^{\mathrm{a}}$ \\
\hline & & & M.spicatum & $11.4 \pm 0.5^{\mathrm{a}}$ & $35.9 \pm 2.0^{\mathrm{a}}$ \\
\hline & & & V.natans & $12.1 \pm 0.5^{\mathrm{a}}$ & $31.3 \pm 2.0^{\mathrm{a}}$ \\
\hline \multirow{9}{*}{$\mathrm{TP}$} & \multirow{9}{*}{$3.0 \pm 0.5$} & \multirow{3}{*}{ SMP-A } & C. demersum & $0.03 \pm 0.02^{b}$ & $98.7 \pm 1.0^{\mathrm{b}}$ \\
\hline & & & M.spicatum & $0.05 \pm 0.02^{b}$ & $97.8 \pm 1.0^{\mathrm{b}}$ \\
\hline & & & V.natans & $0.11 \pm 0.02^{\mathrm{b}}$ & $95.6 \pm 1.0^{\mathrm{b}}$ \\
\hline & & \multirow{3}{*}{ SMP-B } & C. demersum & $0.11 \pm 0.02^{\mathrm{b}}$ & $96.7 \pm 1.0^{\mathrm{b}}$ \\
\hline & & & M.spicatum & $0.13 \pm 0.02^{\mathrm{b}}$ & $96.0 \pm 1.0^{\mathrm{b}}$ \\
\hline & & & V.natans & $0.22 \pm 0.02^{\mathrm{b}}$ & $93.6 \pm 1.0^{\mathrm{b}}$ \\
\hline & & \multirow{3}{*}{ SMP-C } & C. demersum & $0.22 \pm 0.02^{\mathrm{b}}$ & $93.1 \pm 1.0^{\mathrm{b}}$ \\
\hline & & & M.spicatum & $0.37 \pm 0.02^{b}$ & $87.8 \pm 1.0^{\mathrm{b}}$ \\
\hline & & & V.natans & $0.74 \pm 0.02^{b}$ & $76.2 \pm 1.0^{\mathrm{b}}$ \\
\hline \multirow{9}{*}{ DCOD } & \multirow{9}{*}{$65.0 \pm 5.0$} & \multirow{3}{*}{ SMP-A } & C. demersum & $1.0 \pm 1.0^{\mathrm{a}}$ & $99.0 \pm 1.0^{\mathrm{a}}$ \\
\hline & & & M.spicatum & $1.0 \pm 1.0^{\mathrm{a}}$ & $99.0 \pm 1.0^{\mathrm{a}}$ \\
\hline & & & V.natans & $19.0 \pm 3.0^{\mathrm{a}}$ & $71.6 \pm 3.0^{\mathrm{a}}$ \\
\hline & & \multirow{3}{*}{ SMP-B } & C. demersum & $1.0 \pm 1.0^{\mathrm{a}}$ & $99.0 \pm 1.0^{\mathrm{a}}$ \\
\hline & & & M.spicatum & $1.0 \pm 1.0^{\mathrm{a}}$ & $99.0 \pm 1.0^{\mathrm{a}}$ \\
\hline & & & V.natans & $1.0 \pm 1.0^{\mathrm{a}}$ & $99.0 \pm 1.0^{\mathrm{a}}$ \\
\hline & & \multirow{3}{*}{ SMP-C } & C. demersum & $1.0 \pm 1.0^{\mathrm{a}}$ & $99.0 \pm 1.0^{\mathrm{a}}$ \\
\hline & & & M.spicatum & $7.0 \pm 3.0^{\mathrm{a}}$ & $89.1 \pm 3.0^{\mathrm{a}}$ \\
\hline & & & V.natans & $15.0 \pm 3.0^{\mathrm{a}}$ & $77.6 \pm 3.0^{\mathrm{a}}$ \\
\hline
\end{tabular}

$\mathrm{NH}_{4}-\mathrm{N}$ removal than the Vallisneria natans pond, indicating that the photosynthetic aeration capacity of Ceratophyllum demersum and Myriophyllum spicatum was stronger than that of Vallisneria natans. The higher macrophyte density of SMP-A provided an abundant oxygen environment for the efficient occurrence of 


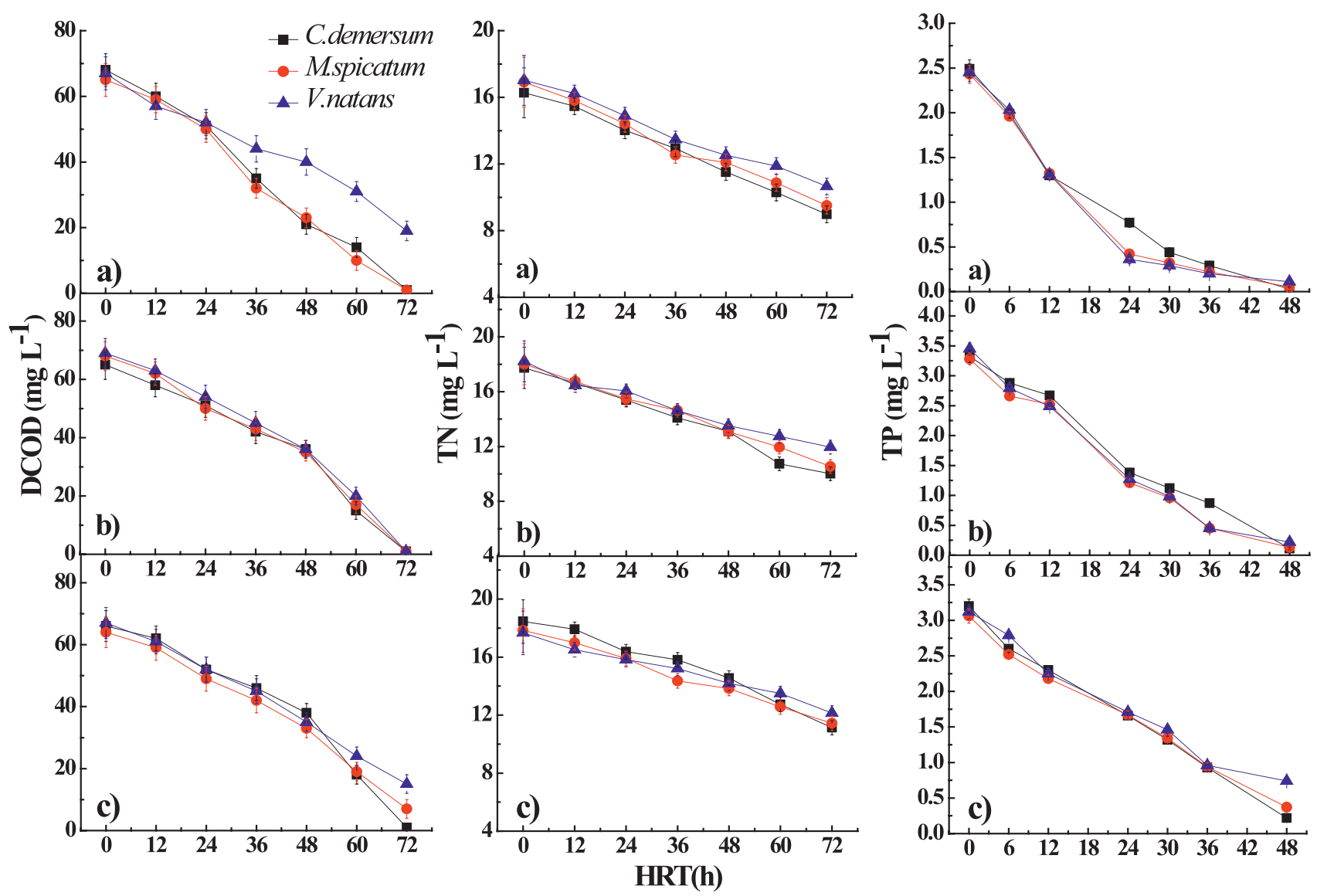

Fig. 2. Profiles of DCOD, TN and TP in SMP-A a), SMP-B b) and SMP-C(c).

nitrification process, and thus $\mathrm{NH}_{4}-\mathrm{N}$ removal in SMP-A was higher compared to SMP-B. The removal efficiency of $\mathrm{NH}_{4}-\mathrm{N}$ in SMP-C was significantly lower than that in SMP-A and SMP-B $(p<0.05)$. This phenomenon could be explained by two facts. Firstly, the low temperature in autumn affected the growth and $\mathrm{NH}_{4}-\mathrm{N}$ assimilation of macrophytes. Secondly, the short lighting period and the weak lighting intensity in autumn influenced photosynthetic aeration of macrophytes, thus creating unfavorable conditions for aerobic nitrification [15]. As illustrated in Table 2, TN concentration in the three macrophyte ponds steadily decreased with HRT. However, the deviations between $\mathrm{TN}$ and $\mathrm{NH}_{4}-\mathrm{N}$ removals reached $10-13 \%$. The unidealistic TN removal performance was due to the limitation of denitrification resulting from the overall aerobic conditions. Although accumulated $\mathrm{NO}_{3}-\mathrm{N}$ could be partly removed by macrophyte uptake, residual $\mathrm{NO}_{3}-\mathrm{N}$ affected $\mathrm{TN}$ removal [16]. Higher macrophyte density and retention time enhanced TN removal in experimental units. The removal efficiency of TN in summer tests (SMP-A and SMP-B) was significantly higher than that in SMP-C of autumn tests $(p<0.05)$.

Phosphorus in SMPs was usually removed by macrophyte uptake, microbial mineralization and chemical precipitation [17]. Submerged macrophytes can assimilate phosphorus for self-growth and provide attachment areas for microbial communities. TP concentration decreased sharply with HRT due to the integrated mechanisms in SMPs (Fig. 2). When the HRT was $48 \mathrm{~h}$, the results of summer tests showed that average TP removal was over $90 \%$ in three kinds of SMPs. TP removal was higher in SMP-A than that in SMP-B. The higher macrophyte density of SMP-A was probably responsible for efficient removal of phosphorus. As presented in Table 2, the Ceratophyllum demersum pond had the capacity to remove TP more efficiently than the other two ponds in summer tests. Average TP removal was lower in SMP-C due to the slow growth of macrophytes and microorganisms affected by the low temperature and weak lighting intensity of autumn months. TP removal in Myriophyllum spicatum and Vallisneria natans ponds of SMP-C was significantly lower than that in summer tests $(p<0.05)$.

DCOD was degraded into inorganic compounds under aerobic conditions, which were then utilized by submerged macrophytes [18]. Photosynthetic aeration of submerged macrophytes further improved the oxygen level of SMP, which was conducive to the aerobic degradation of DCOD. Hence, organic matter can be purified continuously in SMPs. DCOD content gradually decreased with HRT in experimental units (Fig. 2). DCOD in the effluent of summer tests could hardly be detected (with the exception of Vallisneria natans pond in SMP-A, which was ascribed to the limited oxygen level). During autumn tests, DCOD was still not being 
detected in the Ceratophyllum demersum pond, which indicated the capacity of Ceratophyllum demersum for $\mathrm{O}_{2}$ supplement. In contrast, DCOD removal was significantly lower in the Myriophyllum spicatum and Vallisneria natans ponds of SMP-C $(p<0.05)$. The low temperature and deficiency of light supply in autumn affected the photosynthesis of macrophytes, thus leading to undesirable DCOD removal.

\section{Conclusions}

Ecological remediation of eutrophic water by submerged macrophyte pond was achieved in this study. Water purification performance of SMPs was better in summer tests compared with autumn tests due to the flourishing growth of submerged macrophytes under favorable conditions. The results indicated that Myriophyllum spicatum and Vallisneria natans could be more effective in algae inhibition than Ceratophyllum demersum. However, nutrient removal was improved significantly in the presence of Myriophyllum spicatum and Ceratophyllum demersum. Algae and pollutant reductions by all three macrophyte ponds could be enhanced with higher macrophyte density and retention times. In summary, Myriophyllum spicatum was proven to have great potential for remediation of eutrophic water. The findings may provide a low-cost and ecofriendly option for efficient remediation of eutrophic water.

\section{Acknowledgements}

This study was supported by the National Natural Science Foundation of China (grant Nos. 51809162 and 51679041).

\section{Conflict of Interest}

The authors declare no conflict of interest.

\section{References}

1. CHEN J.Z., ZNAHNG H.Y., HAN Z.P., YE J.Y., LIU Z.L. The influence of aquatic macrophytes on Microcystis aeruginosa growth. Ecol. Eng., 42, 130, 2012.

2. ZHANG Y.W., WEI D.Y., MORRISON L., GE Z.B., ZHAN X.M., LI R.H. Nutrient removal through pyrrhotite autotrophic denitrification: Implications for eutrophication control. Sci. Total Environ., 662, 287, 2019.

3. LI J.H., YANG X.Y., WANG Z.F., SHAN Y., ZHENG $Z$. Comparison of four aquatic plant treatment systems for nutrient removal from eutrophied water. Bioresour. Technol., 179, 1, 2015.

4. Freeman A.I., SURRIDGE B.W.J., MATTHEWS M., STEWART M., HAYGARTH P.M. New approaches to enhance pollutant removal in artificially aerated wastewater treatment systems. Sci. Total Environ., 627, $1182,2018$.

5. LU B., XU Z.S., LI J.G., CHAI X.L. Removal of water nutrients by different aquatic plant species: An alternative way to remediate polluted rural rivers. Ecol. Eng., 110, 18, 2018.

6. WANG L., SUN J., ZHENG W.P., HUANG T., ZHANG Y., WU Z.B., HE F. Effects of a combined biological restoration technology on nitrogen and phosphorus removal from eutrophic water. Polish J. of Environ. Stud., 27 (5), 2293, 2018

7. ZENG L., HE F., DAI Z.G., XU D., LIU B.Y., ZHOU Q.H., WU Z.B. Effect of submerged macrophyte restoration on improving aquatic ecosystem in a subtropical, shallow lake. Ecol. Eng., 106, 578, 2017.

8. MOHAMED Z.A. Macrophytes-cyanobacteria allelopathic interactions and their implications for water resources management - A review. Limnologica, 63, 122, 2017.

9. ZHANG Q., LIU Y.-P., LUO F.-L., DONG B.-C., YU F.-H. Does species richness affect the growth and water quality of submerged macrophyte assemblages? Aquat. Bot., 153, $51,2019$.

10. GAO Y.-N., LIU B.-Y., XU D., ZHOU Q.-H., HU C.-Y., GE F.-J., ZHANG L.-P., WU Z.-B.. Phenolic compounds exuded from two submerged freshwater macrophytes and their allelopathic effects on Microcystis aeruginosa. Pol. J. Environ. Stud., 20 (5), 1153, 2011.

11. WANG J., ZHU J.-Y., LIU S.-P., LIU B.-Y., GAO Y.N., WU Z.B.. Generation of reactive oxygen species in cyanobacteria and green algae induced by allelochemicals of submerged macrophytes. Chemosphere, 85 (6), 977, 2011.

12. BAUER N., BLASCHKE U., BEUTLER E., GROSS E.M., JENETT-SIEMS K., SIEMS K., HILT S. Seasonal and interannual dynamics of polyphenols in Myriophyllum verticillatum and their allelopathic activity on Anabaena variabilis. Aquat. Bot., 91 (2), 110, 2009.

13. WANG Y.H., SONG X.S., LI H.W., DING Y. Removal of metals fromwater using a novel high-rate algal pond and submerged macrophyte pond treatment reactor. Water Sci. Technol., 79 (8), 1447, 2019.

14. SOANA E., BARTOLI M. Seasonal regulation of nitrification in a rooted macrophyte (Vallisneria spiralis L.) meadow under eutrophic conditions. Aquat. Ecol., 48, 11, 2014.

15. SU H.J., CHEN J., WU Y., CHEN J.F., GUO X.C., YAN Z.B., TIAN D., FANG J.Y., XIE P. Morphological traits of submerged macrophytes reveal specific positive feedbacks to water clarity in freshwater ecosystems. Sci. Total Environ., 684, 578, 2019.

16. SANDOVAL-GIL J.M., ÁVILA-LÓPEZ M.D.C., CAMACHO-IBAR V.F., HERNÁNDEZ-AYÓN J.M., ZERTUCHE-GONZÁLEZ J.A., CABELLO-PASINI A. Regulation of nitrate uptake by the seagrass Zostera Marina during upwelling. Estuar. Coast., 42, 731, 2019.

17. GAO J.Q., XIONG Z.T., ZHANG J.D., ZHANG W.H., OBONO MBA F. Phosphorus removal from water of eutrophic Lake Donghu by five submerged macrophytes. Desalination, 242 (1-3), 193, 2009.

18. OBRADOR B., PRETUS J.L. Budgets of organic and inorganic carbon in a Mediterranean coastal lagoon dominated by submerged vegetation. Hydrobiologia, 699 (1), 35, 2012. 